\title{
Impact of amorphous calcium carbonate on carbon isotope signatures of biogenic $\mathrm{Ca}-\mathrm{Mg}$ carbonate
}

\author{
ChONGHONG ZHANG*, FuCHUN LI, Jun SUN
}

Nanjing Agricultural University, Nanjing, China

(*correspondence:zchcr2019@163.com)

\section{Experimental Result}

In order to clarify the impact of amorphous calcium carbonate (ACC) on carbon isotope signatures of carbonate in the presence of bacteria, mineralization experiments were carried out in the systems with Arthrobacter sp. MF-2. The results show that the $\delta^{13} \mathrm{C}$ values of $\mathrm{Ca}-\mathrm{Mg}$ carbonate minerals gradually decreased during the initial stage of mineralization process (0 20 days) and remained relatively stable during $20 \sim 50$ days (Fig. 1). It is worth noting that large carbon isotope fractionation associated with the transformation process from ACC to crystallographic carbonate regardless of $\mathrm{Mg} / \mathrm{Ca}$ molar ratio in culture media.

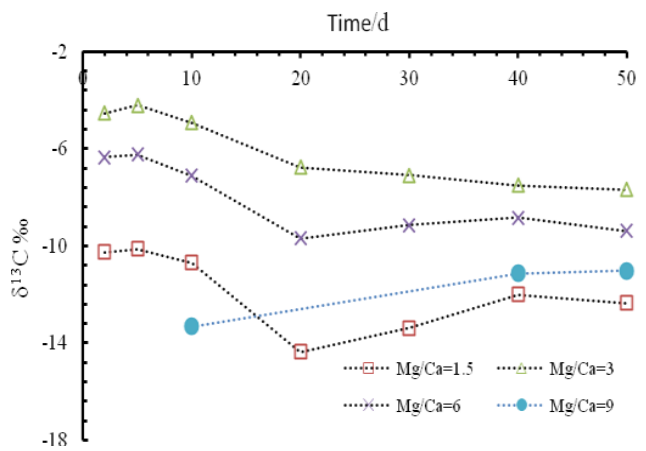

Figure 1 Temporal changes of the $\delta^{13} \mathrm{C}$ of $\mathrm{Ca}-\mathrm{Mg}$ carbonate induced by strain $\mathrm{HJ}-1$

\section{Discussion of Result}

The changes of $\delta^{13} \mathrm{C}$ values of carbonate minerals reflect that the carbon isotope composition of minerals was affected by bacterial metabolism. At the same time, the effect of ACC on carbon isotope composition also could not be ignored. Although strain $\mathrm{HJ}-1$ preferentially oxidized light carbon $\left({ }^{12} \mathrm{C}\right)$ during the bacterial mineralization process and produced more ${ }^{12} \mathrm{CO}_{3}{ }^{2-}$ in culture media, the high percentages of $\mathrm{Mg}$ in ACC accelarated the combination of ${ }^{13} \mathrm{CO}_{3}{ }^{2-}$ and $\mathrm{Ca}^{2+}$ in the initial stage. In addition, the disordered structure of ACC and its dissolution-recrystallization process resulted in significant fractionation of carbon isotopes. 